\title{
POSICIONAMENTO ESTRATÉGICO DOS AGENTES FOMENTADORES NA IMPLANTAÇÃO DA TV DIGITAL NO BRASIL: DISPUTAS, NEGOCIAÇÕES E ESTRATAGEMAS RETÓRICOS ${ }^{1}$
}

\section{STRATEGIC POSITIONING OF FOMENTADORES AGENTS IN THE DEPLOYMENT OF DIGITAL TV IN BRAZIL: DISPUTES, NEGOTIATIONS AND STRATAGEMS RHETORICAL TERMS}

\author{
Roberto Bazanini ${ }^{2}$ \\ Mauricio Donato $^{3}$ \\ Denis Donaire $^{4}$ \\ Ademir Antonio Ferreira ${ }^{5}$
}

\begin{abstract}
RESUMO: As negociações constituem a essência das discussões e disputas presentes nos diferentes setores das atividades concorrenciais. Partindo-se do conceito da atividade do administrador como ciência social aplicada, o objetivo do trabalho está em investigar as polêmicas envolvidas nos estratagemas retóricos empregados pelos seis principais agentes envolvidos no processo de implantação da TV digital no Brasil e, concomitantemente, analisar e discutir os interesses de cada um desses agentes como participativos da decisão técnica/política da escolha do padrão de TV digital. Por intermédio de pesquisa exploratória de natureza qualitativa, análise pósfactum, com emprego da técnica de entrevista embasada na fusão de três referenciais teóricos relacionados ao posicionamento estratégico, especificamente, a Estratégia Decidida Continuamente, Nova Retórica e Análise Retórica., buscou-se delinear as diferentes etapas do processo que culminaram na outorga do padrão digital da TV brasileira em 02 de dezembro de 2007. Os resultados da pesquisa apontam que a adoção do padrão japonês ocorreu em perfeita consonância com os interesses dos Radiodifusores e do Governo Federal, em detrimento dos interesses do Coletivo Intervozes, da Indústria de Telecoms e da Academia, sendo que, para a Indústria de Eletro-eletrônicos não houve interferências significativas no seu modelo de negócio. Esse caso constitui um instrutivo exemplo do processo de negociação no emprego das estratégias por parte dos executivos atuando como agentes retóricos na defesa dos interesses de suas respectivas organizações.
\end{abstract}

PALAVRAS-CHAVE: Estratégia; Retórica; TV Digital

ABSTRACT: The negotiations constitute the essence of the quarrels and disputes gifts in the different sectors of the struggle activities. Breaking itself of the concept of the activity of the administrator as social science applied, the objective of the work it is in investigating the involved controversies in the rhetorical stratagems used by the six main involved agents in the process of implantation of the digital TV in Brazil and, concomitantly, to analyze and to argue the interests of each one of these agents as participants of the decision technique/politics of the choice of the standard of digital TV. For intermediary of exploratoria research of qualitative nature, analysis after-factum, with job of the technique of interview in depth based in the fusing of three related theoretical referenciais to the strategical positioning, specifically, the Determined Strategy Continuously, New Rhetoric and Rhetorical Analysis., searched to delineate the different stages of the process that had culminated in the grant of the digital standard of the Brazilian TV in 02 of December of 2007. The results of the research point with respect to the adoption of the Japanese standard in perfect accord with the interests of the Broadcasters and the Federal Government, in detriment of the interests of the Collective Intervozes, the Industry of Telecoms and the Academy, being that, for the Electro-electronic Industry it did not have significant interferences in its model of business. This in case that it constitutes an instructive example of the process of negotiation in the job of the strategies on the part of the executives acting as rhetorical agents in the defense of the interests of its respective organizations.

\section{KEY WORDS: Strategy; Digital TV; Rhetorical}

\footnotetext{
${ }^{1}$ Artigo Recebido em 09.11.2008. Revisado por pares em 01.05.2009. Recomendado em 25.02.2010 por Leomar dos Santos Editor. Publicado em 06.03.2010.

Organização Responsável pelo periódico: Universidade regional de Blumenau - FURB - www.furb.br/rn
}

\footnotetext{
${ }^{2}$ Universidade Paulista - UNIP - roberto.bazanini@terra.com.br

${ }^{3}$ Faculdade Cásper Líbero - donatotv@terra.com.br

${ }^{4}$ Universidade Municipal de São Caetano do Sul - denisdon@terra.com.br

${ }^{5}$ Universidade São Paulo - USP- adefer@usp.br
} 


\section{INTRODUÇÃO}

A disciplina negociação como conteúdo obrigatório foi instituída na Faculdade de Administração de Harvard em 1993, tendo sido a primeira grande Universidade de Administração nos Estados Unidos a tomar essa decisão.

Anteriormente a essa obrigatoriedade, a Escola de Direito servia como fonte maior das teorias de negociação desenvolvidas na Universidade, visto que os professores de negociação das escolas de Direito e de Administração de Harvard rotineiramente ministram aulas para o corpo discente de ambas, assim como, muitas vezes, servem nos órgãos de direção das duas escolas.

Com o intuito de alcançar à claridade na exposição da teoria presente na integração entre os cursos de Direito e Administração, a fusão dessas duas abordagens foram reunidas sob a chancela da "Teoria de Harvard", nas quais se destacam vários professores que sistematizaram as teorias de negociação:

Bazerman (1994) define a negociação como comunicação feita com o propósito de persuasão que constitui o mais preeminente modo de resolução de conflitos em razão de seu baixo custo operacional.

Nessa perspectiva, a posição em uma negociação é definida em consonância com os objetivos das partes envolvidas. Por outro lado, os interesses constituem razão do pedido de cada uma das partes. A noção de se concentrar em interesses e não em posições permite que se desenvolvam opções que satisfaçam concomitantemente os interesses de ambas as partes produzindo maiores probabilidades de obtenção de um acordo.

Fisher e Ury (1985) advertem que os interesses divergem ao serem considerados os dois lados da negociação, visto que numa resolução conjunta de problemas, é preciso saber quais são os interesses do negociador, assim como os da outra parte. Recomenda a determinação dos próprios interesses por ordem de prioridades, para não se cometer o erro de trocar um interesse menos importante por um mais importante. Decorre daí, que é preciso, inicialmente, não confundir posições com interesses. Posições são as coisas concretas que o negociador afirma que deseja, enquanto os interesses são os aspectos intangíveis que justificam aquela posição. Para atingir um acordo que satisfaça os dois lados, o negociador deve, portanto, atentar aos interesses das partes envolvidas.

Fisher; Ury; Patton (1991) enfatizam que o negociador deve tentar adotar a habilidade mais preciosa em uma negociação, colocar-se no lugar das outras partes envolvidas, tentando compreender o ponto de vista e os interesses dessas partes para alcançar os seus próprios interesses.

Em relação ao objeto de estudo da presente pesquisa, as negociações sobre o modelo de TV digital implantado no Brasil em 02 de dezembro de 2007, durou mais de treze anos. Em virtude do dinamismo dos debates, na defesa de seus respectivos interesses, os atores foram modificando suas posições iniciais em resposta a uma nova situação retórica que a cada nova fase apresentava decorrente da disposição de forças presentes no ambiente. Os resultados da pesquisa apontam para a adoção do padrão japonês (em perfeita consonância com os interesses dos Radiodifusores e do Governo Federal) em detrimento dos interesses da sociedade civil (buscavam a democratização) e da Indústria de Telecom (favorável ao modelo europeu). As indústrias de Eletro-eletrônicos acentuaram a necessidade da interatividade, embora para esses, tanto a multi-programação, bem como a mono-programação, eram aceitáveis uma vez que não provoca interferências no seu modelo de negócio. Por isso, o discurso dessa Indústria primou por um posicionamento efetivo em relação à adoção de uma tecnologia nativa que mesmo não sendo inteiramente viável fosse constituída com 
componentes nacionais. A academia, por sua vez, defendia o padrão brasileiro, por isso, na fase final do processo, buscou identificar-se com a posição do Governo Federal, visto que são dependentes das verbas de pesquisa.

O objetivo do trabalho está em investigar as estratégias de posicionamento empregadas pelos principais agentes envolvidos no processo de implantação da TV digital no Brasil e, concomitantemente, analisar e discutir os interesses de cada um desses agentes fomentadores como participativos da decisão técnica/política da escolha do padrão de TV digital.

O problema da pesquisa está em analisar três aspectos essenciais da implantação da TV digital no Brasil ao questionar:

a) Quais foram os diferentes interesses em jogo na implantação da TV digital?

b) A escolha do padrão japonês beneficia quais agentes fomentadores?

c) Como o posicionamento adotado pelos diferentes agentes nas diferentes fases da negociação favoreceu seus interesses?

Com base nesses questionamentos, Fisher e Ury (1985) apontam três possibilidades básicas presentes no processo de negociação com vistas ao acordo a ser alcançado:

1) Que acordo o negociador gostaria de obter, que atendesse a todos os seus interesses e, ao mesmo tempo, atendesse a pelo menos um mínimo de interesses de outra parte, de forma que eles concordassem com essa proposta?

2) Que acordo contentaria o negociador? Esse tipo de acordo atende os interesses da parte interessada e a deixaria relativamente satisfeita.

3) Que acordo o negociador suportaria?

Essas três possibilidades estiveram continuamente presentes em relação ao processo de negociação entre os agentes fomentadores em inúmeros momentos e situações para a escolha do padrão de modelo a ser adotado no Brasil

Portanto, com base nos referenciais teóricos relacionados às estratégias empregadas na negociação, a ênfase da pesquisa está direcionada, primordialmente, para a análise do posicionamento adotado pelos principais agentes fomentadores envolvidos, tendo como base os discursos empregados nas diferentes fases do processo que culminou na escolha do modelo de TV digital para o Brasil.

\section{REVISÃO BIBLIOGRÁFICA}

Existem inúmeros trabalhos acadêmicos que discorrem sobre a relação entre negociação, estratégia, retórica referente à atuação dos grupos de poder envolvidos com os meios de comunicação de massa. Galperin (2004) analisa a implantação da TV digital nos Estados Unidos e na Inglaterra; Hart (2004) estuda as diferentes características da TV digital nos Estados Unidos, Europa e Japão; Antonoff (2007) aborda os rumos e tendências da TV digital a curto e médio prazo. Especificamente, em relação ao Brasil, duas abordagens são predominantes:

1. Posicionamento estratégico e análise do discurso. (Bazanini, 1998) analisa os componentes dos formatos organizacionais empregados pelos grupos de poder voltados para o mercado de bens simbólicos em duas emissoras televisivas brasileiras: Rede Globo e Rede Record.

2. Abordagens de caráter sociológico. Torres (2005) analisa as estratégias empregadas em decorrência das alterações no mercado de TV por assinatura no Brasil em um momento, identificado pelo autor, como "de reestruturação e reposicionamento das empresas diante da crise financeira e da convergência tecnológica". 
Especificamente em relação ao tema implantação digital, na perspectiva, também, da análise sociológica, alguns trabalhos merecem destaque. A tese de Crocomo (2004) propõe um processo para que seja possível o exercício pleno da interatividade, uma das principais qualidades da prometida TV digital brasileira. Outra tese, do pesquisador Renato Cruz (2006) leva em conta as questões políticas, tecnológicas e econômicas da escolha do padrão digital da TV brasileira. Montez \& Becker (2005), abordam, basicamente, as diferenças entre a TV analógica e a TV digital; Godoy Piccolo (2008) discorre sobre a aplicação da TV digital nas atividades governamentais.

Entretanto, se existem várias pesquisas relacionadas aos aspectos sociológicos resultantes da implantação da TV digital, o mesmo não ocorre em relação às abordagens voltadas para a análise do discurso e estratégias de posicionamento empregadas pelos principais atores que estiveram diretamente envolvidos na decisão da escolha do novo padrão da televisão para o Brasil.

Como teoria da negociação, os pressupostos presentes na tipologia da Estratégia Decidida Continuamente ressaltam a estratégia como elemento orientador e flexível das situações que podem ser alteradas a qualquer momento em decorrência do estudo e monitoramento das ações dos concorrentes. Por isso, essa orientação é utilizada, principalmente, nos processos de negociação quando existe a possibilidade de alcançar vantagens por meio da influência exercida no comportamento dos parceiros que segundo Coughlan (2001), pode corresponder à possibilidade de empregar diferentes tipos estratégias: estratégia de prometer, estratégia de ameaçar, estratégia baseada na lei, estratégia de pedir, estratégia de trocar informações e estratégia de recomendar.

$\mathrm{Na}$ perspectiva da Estratégia Decidida Continuamente, de acordo com Martinelli e Almeida (1998), cada agente envolvido em uma negociação tem uma visão particular das situações com base no seu ponto de vista e sua conveniência, que até mesmo se altera em situações diversas ao longo do tempo em consonância com a ação dos concorrentes.

No entanto, em qualquer situação, objetivo da negociação, importância e oportunidade, os autores definem as estratégias como três variáveis básicas influenciando esse processo: poder e dependência, informação e tempo.

A dinâmica do poder e da dependência são fatores importantes a serem considerados, pois eles permitem uma visão de como a estrutura do canal pode influenciar a desempenho da negociação. O poder pode ser definido como a habilidade de um ator (A) conseguir de um outro ator (B) aquilo que ele deseja (Hogarth-Scott, 1999).

Assim, o presente trabalho pretende preencher essa lacuna ao apresentar e analisar as características das estratégias de posicionamento empregadas na implantação da TV digital no Brasil, contribuindo, desse modo, para um melhor entendimento sobre o tema.

\section{METODOLOGIA}

Na elaboração desse trabalho, inicialmente, procedeu-se uma revisão da bibliografia sobre o tema com base em três referenciais teóricos: Estratégias Decididas Continuamente, a Nova retórica com ênfase no estudo do emprego das estratégias retóricas na perspectiva da metodologia da Análise Retórica, mais especificamente no modelo dos seis passos propostos pela pesquisadora Tereza Lúcia Halliday (1987), para análise das estratégias empregadas pelos retores das organizações na defesa de seus interesses e, consequentemente, na consecução de seus objetivos.

Posteriormente, por intermédio de pesquisa exploratória de natureza qualitativa, análise pós-factum, com emprego de instrumento de coleta de dados voltados para 
POSICIONAMENTO ESTRATÉGICO DOS AGENTES FOMENTADORES NA IMPLANTAÇÃO DA TV DIGITAL NO BRASIL: DISPUTAS, NEGOCIAÇÕES E ESTRATAGEMAS RETÓRICOS

interpretação das respostas livres dos principais agentes fomentadores embasados nos conceitos e definições sobre interesses e sistemas de crenças que na perspectiva de Krüger (1995), conforme quadro 1.

\section{Questões}

1. Como o Sr. concebe a evolução da digitalização da TV e a implantação da TV Digital no Brasil?

2. Quais foram os diferentes interesses em jogo na implantação da TV digital?

3. Qual a sua posição em relação a promulgação do Decreto 4901/03 e Decreto $5820 / 06$ ?

4. A escolha do padrão japonês beneficia quais agentes fomentadores?

\section{Quadro 1 - Roteiro das Entrevistas}

A técnica das respostas livres vincula-se um determinado nível de consciência, o qual pode variar em uma linha de continuidade desde um momento em que pese a dificuldade de compreensão e percepção podem ser formuladas positiva ou negativamente, isto é, afirmandose ou negando-se a relação entre objetos e/ou propriedades destes. $\mathrm{O}$ grau de compatibilidade ou congruência apresentado pelas crenças e interesses manifestados contribuem para a extensão da condição de aceitabilidade das mesmas como reconstrução de uma pesquisa realizada pós-factum realizado pelo pesquisador.

Essa técnica permite o dialogo do pesquisador em relação às respostas livres dos entrevistados o que possibilita a divisão do estudo em fases distintas para um melhor entendimento do problema.

Foram entrevistados os seguintes agentes fomentadores: Governo Federal, Ara Minassian (Superintendente da ANATEL); Radiodifusores, Roberto Franco (Diretor de Tecnologia do SBT e presidente da SET) Indústria de Eletro-Eletrônicos, Morris Ardid, Vicepresidente da Gradiente; Sociedade Civil, Diogo Moisés (Diretor do Coletivo Intervozes); Marcelo Zuffo (Universidade São Paulo - USP), totalizando mais de 20 horas de gravação..

Diante desse montante de horas das entrevistas com respostas livres, faz-se necessário dois esclarecimentos básicos:

a) Não sendo possível transcrever o texto em sua íntegra no corpo do trabalho, optou-se pela resenha de algumas falas, transcrevendo literalmente outras que julgamos essenciais para a compreensão dos procedimentos retóricos.

b) Se compararmos essas transcrições ao texto em sua íntegra, certamente constataremos a presença de flutuações e divergências ligadas ao processo de seleção e delimitação, resultantes da própria natureza pessoal da decodificação e do contexto situacional.

Desse modo, nos processos de transcrição, certamente estarão presentes algumas transgressões que, entendemos não comprometem o trabalho em sua essência, como afirma Marcuschi (1986, p.9): "Não existe a melhor transcrição. Todas são mais ou menos boas. O essencial é que o analista saiba quais os seus objetivos e não deixe de assinalar o que convém."

Para amenizar essas possíveis transgressões, buscou-se reproduzir o mais fielmente possível as repetições e ênfases dos entrevistados em relação às quatro temáticas abordadas.

\subsection{Fases da Pesquisa}

Stone, Patton e Heen (1999) enfatizam que a maioria das negociações possuem elementos comuns, dentre os quais se destaca a "negociação sobre o que aconteceu", visto que 
o que deveria ter acontecido no curso das interações entre os participantes conduz à necessidade de reparação do ocorrido.

Com o intuito de analisar "a negociação sobre o que aconteceu" e, consequentemente, detectar o posicionamento de cada agente envolvido, com base nas respostas livres dos entrevistados, a pesquisa foi dividida em três fases distintas: primeira fase (1994-2003); segunda fase (2003-2006) e por fim à terceira fase (2006-2007).

A primeira fase corresponde ao período de 1994 a 2003, no qual foram realizados os primeiros testes relativos aos padrões de modulação dos sistemas: Europeu (DVB), NorteAmericano (ATSC) e Japonês (ISDB).

A segunda fase compreende o período de 2003 a 2006, com ênfase no Decreto 4901/03 que define 11 (onze) objetivos para o Sistema Brasileiro de TV Digital (SBTVD), quase todos de natureza social ou cultural: inclusão digital, promoção da cultura brasileira, expansão da educação à distância, fomento ao desenvolvimento industrial e tecnológico nacional, fortalecimento das emissoras atuais e o estímulo à entrada de novos produtores e difusores. O decreto determinou ainda que recursos do Fundo Nacional para o Desenvolvimento das Telecomunicações (Funtel) fossem aplicados em pesquisas para o desenvolvimento de um sistema brasileiro de TV digital. Durante dois anos, 20 consórcios universitários, com recursos de aproximadamente $\mathrm{R} \$ 60$ milhões, desenvolveram quase todos os módulos necessários à montagem de um sistema, inclusive as camadas de modulação, compressão de sinal e middleware.

A terceira fase, de 2006 a 2007, abordou com especial relevância as discussões que culminaram na outorga do Decreto 5820/06, definindo algumas regras, tais como: o governo pretende conceder um canal adicional, em UHF, a cada atual emissora de TV, sendo que ao final de dez anos a emissora devolverá ao Estado o seu atual canal VHF analógico, retendo o digital. Assim, o decreto indica que essa concessão provisória será em "consignação".

\section{REFERENCIAL TEÓRICO}

Como atributo caracteristicamente humano, a estratégia pode ser concebida como um conjunto coerente de decisões e responsabilidades que um determinado agente assume, em face das diversas eventualidades que será levado a encarar, em virtude tanto das circunstâncias exteriores quanto interiores, como em virtudes de hipóteses que incidem sobre o comportamento dos outros agentes interessados em tais decisões. Bazanini (2007, p.262) esclarece:

Todas as definições de estratégia se assentam na inseparabilidade entre a organização e o meio ambiente que, se por um lado representa uma condicionante à sua atividade, por outro lhe oferece oportunidades que importa aproveitar. $E$ esta relação entre organização e o meio ambiente envolvente que dá sentido ao conceito de estratégia.

Nessa mesma perspectiva estratégica proposta no texto acima, Gracian (1987, p.12) escreveu:

A vida humana é um combate contra a malícia do próprio homem. O homem hábil
nela emprega como armas os estratagemas da intenção... E depois, quando, seu
artifício fica conhecido, aprimora a dissimulação, servindo-se da própria verdade
para enganar. Ele muda de jogo e de bateria, para mudar seu ardil. Seu artifício é
os não ter mais, e toda a sua sagacidade está em passar da dissimulação
precedente à candura. Aquele que o observa e tem penetração conhecendo a
habilidade de seu rival, acautela-se e descobre as trevas revestidas de luz. Decifra
um procedimento tanto mais oculto quanto tudo nele é sincero. 
Os referenciais teóricos das estratégias empresariais estão fortemente relacionados aos pensadores que discorrem sobre negociações, política e arte militar, daí a pertinência da integração estratégia, retórica e posicionamento. Nessa perspectiva, ao conceber que se determinado argumento é verdadeiro, falso ou mesmo semi-verdadeiro isso se torna irrelevante para o estrategista que busca acima de tudo posicionamento favorável, como bem adverte Ries $(1994,4)$ :

O posicionamento trata de reestruturar percepções. Assim a verdade é irrelevante. O que importa são as percepções que existem na mente. A essência da idéia de posicionamento consiste em aceitar as percepções como realidade e então reestruturar essas percepções a fim de criar a posição que você deseja

Desse modo, o posicionamento da organização em relação ao contexto em que a empresa está inserida pode ser considerado um dos elementos indispensáveis para se alcançar vantagem competitiva no mercado de bens simbólicos, cujo substrato condicionante propõe a inseparabilidade entre a organização e meio ambiente. Nessa perspectiva, Zacarelli (2000) elabora instrutivo quadro sobre as origens da estratégia: estratégia emergente, estratégia aprendida, estratégia aprendida e formalizada, estratégia decidida continuamente, conforme quadro2.

\begin{tabular}{|l|l|l|l|l|}
\hline & Origem da Estratégia & $\begin{array}{l}\text { Fonte da } \\
\text { Estratégia }\end{array}$ & $\begin{array}{l}\text { Características } \\
\text { Frase-chave }\end{array}$ & \multicolumn{1}{|c|}{ Perigo } \\
\hline 1 & Emergente & Experiência & $\begin{array}{l}\text { Se deu certo no passado, } \\
\text { deverá continuar no } \\
\text { futuro. }\end{array}$ & $\begin{array}{l}\text { Perda de relevância com o } \\
\text { passar do tempo }\end{array}$ \\
\hline 2 & Aprendida & Livros & $\begin{array}{l}\text { Se a liderança é altamente } \\
\text { recompensadora, o lider } \\
\text { deve copiar a estratégia do } \\
\text { oponente Aprendizado incompleto }\end{array}$ & \\
\hline $3^{\text {a }}$ & $\begin{array}{l}\text { Decidida } \\
\text { formalizada }\end{array}$ & Estudo & $\begin{array}{l}\text { Formalmente organizada e } \\
\text { aprovada na empresa. } \\
\text { Escrita. Nunca é completa }\end{array}$ & $\begin{array}{l}\text { Tornar-se inflexível, ficar } \\
\text { conhecida pelos concorrentes }\end{array}$ \\
\hline $3 b$ & $\begin{array}{l}\text { Decidida } \\
\text { continuamente }\end{array}$ & $\begin{array}{l}\text { Monitorar os } \\
\text { concorrentes }\end{array}$ & $\begin{array}{l}\text { Pode ser alterada a } \\
\text { qualquer momento }\end{array}$ & \\
\hline
\end{tabular}

\section{Quadro2. Origens da Estratégia}

Fonte: o autor, adaptado de Zacarelli 2000, p. 54

Com base no quadro acima, pode-se inferir que a Estratégia Decidida Continuamente é, acentuadamente, pragmática, visto que, supera a experiência do passado; transcende a simples imitação ao mesmo tempo em que, desinforma os concorrentes sobre as decisões que serão tomadas. Mintzberg (2000) associou a Estratégia Decidida Continuamente com a Escola da Configuração. Essa abordagem enfatiza o dinamismo presente no mercado concorrencial, razão pela qual, as empresas, durante um certo período de tempo, configuram determinado modo até o momento que se lhes acometa um período de mudança transformadora e uma nova configuração.

\subsection{Fusão e complementariedade entre os referenciais teóricos}

A retórica foi definida por Aristóteles (1956) como a possibilidade de descobrir teoricamente, em cada passo, o que pode produzir a persuasão. 
Empregada como instrumento de análise no competitivo mercado de bens simbólicos pela sua flexibilidade e imediatismo, tendo como premissa básica o estudo e monitoramento permanente das ações concorrenciais, a Estratégia Decidida Continuamente apóia-se na verossilhança do discurso por intermédio da teoria da argumentação concebida como uma Nova Retórica ao cobrir todo o âmbito do discurso destinado a convencer ou a persuadir, qualquer que seja o auditório a que se dirija e qualquer que seja a matéria que trate.

Por sua vez, a Análise Retórica caracteriza-se por um antigo método de análise do discurso, acentuadamente pragmático, cujas ações podem ser alteradas a qualquer momento pelos enunciadores do discurso e detectadas, prontamente, pelos críticos visto que, permite avaliar a situação retórica em sua totalidade (contexto, intenções do emissor, limitações da audiência). Para se ter uma idéia da aplicabilidade desse instrumento, nos Estados Unidos da América, o Quaterly Journal publica análises completas dos mais diferentes discursos, tendo como suporte um determinado referencial teórico, decorridos somente alguns momentos de seu pronunciamento.

Desse modo, em termos estratégicos, nos processos de negociação, a Estratégia Decidida Continuamente e a Nova Retórica acompanhada da Análise Retórica possuem três características básicas:

1. Expressão da subjetividade - A arte de bem falar para conquistar um determinado público através da persuasão. O caráter argumentativo da retórica sempre esteve presente: persuadimos através de argumentos, porém, o nosso adversário também faz o mesmo, daí sua relação com a estratégia de sinalização, que pode ser entendida como uma estratégia complementar. Zacarelli (2000, p.186) define a estratégia da sinalização como: "aquela que visa a divulgação, seja ela verdadeira ou não, do que convém que os outros acreditem sobre a empresa..."

Nessa perspectiva, retórica e argumentação são sinônimos. Ambos são processos racionais de tomada de decisões através do uso da linguagem em situações de incerteza, verossimilhança e probabilidade.

2. Conceito de razoável e lógica do bom senso - Adesão e negociação são complementares. A Nova Retórica propõe que a finalidade da retórica é a adesão: o objeto desta teoria é o estudo das técnicas discursivas que permitem provocar ou aumentar a adesão dos espíritos às teses apresentadas ao seu assentimento (Perelman, 1996, 5). Por sua vez, a Análise Retórica concebe a retórica basicamente como negociação: a retórica possui função reparadora num mundo repleto de facções e interesses conflitantes, no qual o dilema da convivência humana faz surgir uma situação retórica universal (Burke $(1966,34)$.

A adesão de Perelman e a negociação de Burke convergem para um mesmo ponto: a atividade retórica é o encurtamento (ou o alargamento) da distância entre os sujeitos referente a um determinado problema, daí sua relação com outras estratégias complementares, como as alianças estratégicas. Zacarelli (2000) afirma que as alianças estratégicas, ou estratégicas coletivas, são muito importantes para incrementar as vantagens competitivas das organizações que se aliam na consecução de seu objetivos.

3. Crítica e questionamento - É possível para qualquer cidadão ser um analista do discurso, seja de forma crítica, por vezes de forma ingênua, por vezes de modo coerente, através de questionamentos sobre as situações, fatos e acontecimentos à nossa volta, conforme propõe as premissas da abordagem da Nova Retórica e da Análise Retórica. Perelman (1996, 4) concebe a retórica como comunicação persuasiva que busca o assentimento daqueles a quem o discurso se dirige, inspirado no modelo de Burke $(1966,22)$ segundo o qual nas sociedades democráticas a defesa dos interesses das organizações pela palavra se faz cada vez mais habilmente, uma vez que estamos diante de uma situação retórica universal que pode ser resolvida por meio do discurso. 


\subsection{Os seis passos da Análise Retórica}

A abordagem da Análise Retórica pode ser operacionalizada em diferentes etapas. Os seis passos do método enunciados por Halliday (1986, p. 126-131) permitem compreender as motivações implícitas e explícitas do emissor, as expectativas dos receptores e as contingências do contexto:

!) Os Antecedentes da Situação. Reconstituem-se os elementos históricos, políticos e culturais que pré-condicionaram a instância como uma situação problemática. Segundo Campbell (1982, 37): "No item antecedentes da situação busca-se identificar a situação de momento com as variáveis de ameaças e oportunidades presentes num determinado contexto".

2) O Problema Retórico. Um conflito ou desequilíbrio entre a perspectiva ou posicionamento de um público face ao tema, questão ou situação e a perspectiva ou posicionamento que o retor gostaria que esse mesmo público tivesse. Segundo Campbell (1982, p.69):

Um problema é um hiato entre o que temos e o que queremos ter. Na ação retórica, um retor (o comunicador) confronta um público que percebe, entende, ou acredita de um jeito e (esse mesmo comunicador) quer que esse público perceba, compreenda ou acredite de outro jeito. O problema retórico é um conceito abrangente que inclui todos os obstáculos enfrentados por comunicadores.

3) Anatomia do ato retórico. Identificação dos arqui-argumentos e seus suportes: vocabulários, figuras de linguagem, especialmente as metáforas e slogans que constituem a própria estrutura do discurso. Segundo Tereza Lúcia Halliday (1986, p.127): "Faz-se necessário identificar cada parte do ato retórico, fazendo um levantamento de seu vocabulário, argumentos e figuras de linguagem, que constituem a anatomia do discurso".

4) As Contingências do Discurso. As limitações encontradas pelo retor para realizar seu discurso. Segundo Tereza Lúcia Halliday (1986, p.128): "Todo ato retórico sofre limitações e restrições que contribuem para limitar o conteúdo e a forma."

5) Interpretação. A interpretação do ato retórico segundo determinado arcabouço filosófico que proporciona fundamentação da análise presente nos quatro primeiros passos do método.

6) Julgamento. Analisa-se a validade do ato retórico sob a ótica da eficiência, qualidade e ética.

Esses seis passos enunciam as características básicas da Análise Retórica que ressaltam a expressão da subjetividade, as diversas definições de retórica, a crítica e o questionamento que constituem o cerne da utilização do discurso para a resolução de problemas.

\section{RESULTADOS DA PESQUISA}

Partindo-se do pressuposto que o comunicador empresarial é um retor e um negociador de significados ao definir a realidade de certo ponto de vista para exercer influência sobre situações, genericamente, pode-se afirmar que, por ocasião dos treze anos de 
discussão sobre a implantação da TV digital no Brasil, em decorrência do monitoramento permanente das ações dos agentes fomentadores envolvidos e as inúmeras mudanças de posicionamento realizadas, prevaleceram em relação aos discursos dos agentes, ações relacionadas à estratégia decidida continuamente nas diferentes fases dos debates.

Particularmente, conforme Quadro 3, é possível identificar e classificar o posicionamento e discurso dos agentes fomentadores em consonância com seus respectivos interesses: 1) Governo Federal, com maior foco sob o mandato do Presidente Luis Inácio Lula da Silva e representado pelo Ministério das Comunicações, o CPqD e a ANATEL; 2) Radiodifusores; 3) Sociedade Civil, representada pelo Coletivo Intervozes; 4) Indústria Eletro-eletrônica: 5)Indústria de Telecomunicações; 6) Consórcio das Academias.

\begin{tabular}{|l|ll|}
\hline Governo Federal & $\bullet$ & $\begin{array}{l}\text { Integração e desenvolvimento: Propiciar educação à distância, tele- } \\
\text { medicina, disseminação cultural, comércio eletrônico, } \\
\text { bancários, informações sob demanda, bate-papo e correio eletrônico. }\end{array}$ \\
\hline Radiodifusores & $\bullet$ & $\begin{array}{l}\text { Interesses predominantemente comerciais: Levar conteúdo em alta } \\
\text { definição de som e imagens e manter o modelo de negócio atual, } \\
\text { baseado na venda de audiência para os anunciantes. }\end{array}$ \\
\hline Sociedade Civil & $\bullet$ & $\begin{array}{l}\text { Democratização da informação: A importância do acesso à informação, } \\
\text { entretenimento e interatividade a todos os segmentos da sociedade. }\end{array}$ \\
\hline $\begin{array}{l}\text { Indústria Eletro-eletrônica } \\
\text { Telecomunicações }\end{array}$ & $\begin{array}{l}\text { Interesses predominantemente comerciais: Impulsionar as vendas de } \\
\text { televisores e celulares no país. }\end{array}$ \\
\hline Consórcio das Academias & $\bullet \quad \begin{array}{l}\text { Interesses predominantemente comerciais: Implantar o padrão Europeu } \\
\text { de TV digital (DVB), uma vez que esse padrão representa seus } \\
\text { interesses comerciais e já está estabelecido em mais de cinqüenta países } \\
\text { disseminado entre Europa, Ásia, África, Oceania e Oriente Médio. }\end{array}$ \\
\hline $\begin{array}{l}\text { Interesse pela pesquisa: Desenvolver um padrão com tecnologia } \\
\text { nacional. }\end{array}$
\end{tabular}

\section{Quadro - Discursos dos Atores da TV Digital no Brasil}

Quadro elaborado pelo autor

Esses agentes fomentadores estiveram envolvidos diretamente nas discussões iniciadas em março de 1994 para escolha do padrão da TV digital brasileira, com base em três sistemas, conforme Quadro 4.

\section{Quadro 4 - Sistemas de modulação da TV Digital}

1) O Norte Americano - Advanced Television Systems Committee (ATSC), adotado pelos Estados Unidos, Canadá, México e Coréia do Sul;

2) O Europeu - Digital Vídeo Broadcasting (DVB), adotado em mais de cinqüenta países, incluindo toda a Europa, Austrália, Nova Zelândia, Índia, Cingapura e Taiwan;

3) O Japonês - Integrated System Digital Broadcasting (ISDB), usado apenas no Japão.

Quadro elaborado pelo autor

As estratégias e posicionamento e as disputas na implantação da TV digital no Brasil tiveram como aspectos predominantes na perspectiva da Análise Retórica três fases distintas:

\subsection{PRIMEIRA FASE: "1994 A 2003"}

\section{$1^{\circ}$. passo - Antecedentes da Situação.}

Nesse período iniciaram-se os primeiros debates sobre a possibilidade de implantação da TV digital no Brasil. A situação era incerta quanto aos rumos que os debates tomariam. Os 
defensores da necessidade da imediata implantação de um padrão digital eram os radiodifusores. O Governo federal acenava, timidamente, com essa possibilidade e os demais agentes ainda não tinham se envolvido efetivamente nos debates. Segundo relato de seu representante, Roberto Franco, nesse período, a posição assumida pelos radiodifusores apontava para o Brasil entrando, o mais rapidamente possível, na era digital, visto que o mundo caminhava nessa direção. $\mathrm{O}$ atraso no desenvolvimento desse projeto poderia acarretar sérias conseqüências, tanto no campo tecnológico quanto no campo social. Afirma Roberto Franco - Presidente da SET / Diretor de Tecnologia do SBT:

\begin{abstract}
Havia uma preocupação já que o Japão tinha implantado o MUCE num sistema de alta-definição e a Europa falava em adotar um sistema de alta-definição, o Eureka e outros formatos que eles imaginavam, e os Estados Unidos se via pressionado por demanda do telespectador que queriam um sinal de maior resolução, de maior qualidade, o produtor de conteúdo queria poder entregar conteúdos mais ricos, a caminhar por um sistema de alta-definição e havia uma dificuldade muito grande no mundo analógico para se fazer isso...Em 1994, quando o assunto já vinha sendo discutido, quando já existia o padrão americano sendo proposto até surgir o padrão DVB e o padrão japonês ainda não estava pronto, não estava formalizado. Nós formamos um primeiro grupo de trabalho conjunto de emissoras com coordenação da SET, parceria com a ABERT e o envolvimento posterior da ANATEL, promovido aí na época do ComTV, em que se criou um primeiro grupo de trabalho formal sobre o assunto TV Digital
\end{abstract}

\title{
$2^{\circ}$. passo - O problema Retórico.
}

Os interesses do grupo de radiodifusores, predominantemente comerciais, objetivavam fazer a transição do modelo analógico para o modelo digital. Para isso era necessário convencer os órgãos competentes da pertinência desse empreendimento. Esse período fícou marcado pelos testes desenvolvidos pelos engenheiros brasileiros, em conjunto com a academia, que avaliaram os três sistemas que estavam em debate no mundo: $O$ Norte Americano (ATSC), o Europeu (DVB) e o Japonês (ISDB), como descreve (Roberto Franco Presidente da SET / Diretor de Tecnologia do SBT).

Fizemos os testes, que até hoje são considerados como os mais profundos, e foram base para as propostas que nós fizemos ao ITU sobre metodologia de teste comparativos de sistemas internacionais, que hoje é a recomendação ao ITU sobre comparação, ela nasce com a proposta brasileira, ela é praticamente a proposta brasileira. Eu vejo que esse processo de implantação da TV digital é de grande orgulho para a radiodifusão no Brasil e não só a radiodifusão mas todos os setores envolvidos, eu falo radiodifusão porque o processo iniciou na radiodifusão e talvez o radiodifusor tenha sido o agente mais envolvido durante toda a história

O Governo Federal percebeu que a TV digital transcendia a questão meramente técnica e começou a discutir o assunto do ponto de vista político e estratégico, como afirma Ara Minasian - Superintendente de Comunicação de Massa da Anatel:

O grupo Set/Abert, especialmente SET, desde o início em 2001 ela considerou que o melhor sistema era uma modulação COFDM e que o sistema japonês lhes atendia porque ele tinha alta definição e definição standard. Quando a Anatel juntamente com o CPqD foi a campo nós ratificamos o resultado observado em campo pelas emissoras e nós nunca tivemos dúvida de que a modulação COFDM era melhor do que a modulação 8VSB. Então, dentro da transparência, a agência colocou o resultado de tudo isso ai em consulta pública e além disso, a Anatel naquela ocasião, em 2001, disse o seguinte: "eu estou vendo aqui um cenário ou 
questões estratégicas por detrás da escolhas deste padrão”. Então o Brasil poderia tirar também algum proveito em termos de país ao introduzir essa tecnologia

As indústrias de telecomunicações, cujos interesses maiores também eram comerciais, passaram, naquele momento, a empregar um discurso de que o foco deveria ser sempre voltado ao consumidor, pois, a exemplo da discussão que houve na implantação da tecnologia celular no Brasil (no período de 1997 a 2000), o debate tomou rumos a favor dos europeus (em detrimento do sistema Norte-Americano), que queriam impor o foco na indústria. Afirma o representante da indústria de Telecom:

\begin{abstract}
Mas a discussão pública ela veio a tona em 2.000 mesmo, através de uma consulta pública da Anatel no que seria melhor para o Brasil, ficar no modelo americano ou ir para o modelo europeu, que naquele momento já tinha sido globalizado. Então a discussão foi muito difícil porque nós já tinhamos uma coisa implantada, mas prevaleceu o bom senso naquela época, porque a discussão era aberta, era pública e era centrada na vantagem para o consumidor. Esse era o ponto central. E, após vários anos nós vimos a penetração do celular que não é um aparelho muito barato, excepcionalmente alto, então foi uma história de sucesso.
\end{abstract}

A Academia iniciou seus trabalhos de pesquisa a partir de 1.996, fazendo testes de transmissão do padrão MPEG-2 em alta-definição, conforme comentário do Professor LivreDocente da Escola Politécnica da USP, Marcelo Zuffo: "Os nossos trabalhos se iniciam- em 1996 com testes de transmissão do padrão MPEG-2 em alta definição. A TV digital no Brasil é uma história longa, de quase dez anos..."

A indústria de Eletro-eletrônico esteve pouco envolvida nesse período. Os debates ficaram mais acalorados logo após a promulgação dos decretos que fomentaram a TV digital no Brasil. Como ressalta Morris Arditti, vice-presidente da Gradiente:

Após o decreto 4901/03 os setores representantes do negócio da TV digital sentaram pela primeira vez e conversaram e negociaram, fazendo os compromissos no sentido de ceder ou deixar de ceder em torno das especificações

A sociedade civil representada pelo Coletivo Intervozes, nesse período, estave ausente das discussões sobre TV digital. Começaram a ter uma participação mais efetiva nos debates a partir de 2003, no início da gestão do Deputado Miro Teixeira frente ao Ministério das Comunicações, conforme acentua Diogo Moysés / Conselho diretor do Intervozes:

Eu acho que foi o primeiro grande ponto de virada, aonde você teve no governo Fernando Henrique de tomar a decisão de no final do seu mandato, não tomar decisão alguma sobre a TV digital no Brasil, ele não teve segurança

Em síntese, pode-se afirmar que, nesse primeiro período, começam a ficar claras as parcerias que seguiram, ao longo das discussões, aproximando os agentes fomentadores. Também começam a ficar caracterizadas as posições assumidas por cada ator em defesa de seu próprio interesse.

\title{
$3^{\circ}$. passo - Anatomia da Mensagem
}

A linguagem dos radiodifusores, nesse período, caracterizou-se pela apologia e desenvolvimento, assentada em expressões do gênero, afirma Roberto Franco - Presidente da $S E T$ / Diretor de Tecnologia do SBT: "não podemos mais ficar esperando para migrar para era digital, pois se não entraremos na berlinda da tecnologia e ficaremos a mercê do que foi definido por outros países". 

ESTRATAGEMAS RETÓRICOS

A linguagem do Governo federal, acentuadamente cautelosa, reforçou a idéia de que tal decisão deveria ser analisada em profundidade antes de qualquer definição. Afirma Ara Minasian - Superintendente de Comunicação de Massa da Anatel:

Na realidade nós, até 1995, acompanhávamos os trabalhos da TV digital mas depois disso as autoridades do governo entenderam que a questão da TV digital transcendia uma questão técnica e a Anatel era responsável por questões técnicas. Então se começou a discutir o assunto do ponto de vista político e estratégico e a gente entende que TV digital é uma estratégia

A linguagem da academia voltou-se para a necessidade de desenvolver tecnologia nacional. Como destaca Marcelo Zuffo, Professor Livre-docente da USP:

\begin{abstract}
...eu sempre fui um defensor da importância do desenvolvimento de uma tecnologia nacional e foi com esse intuito que todo o meu interesse é norteado, a possibilidade de se ter componentes essenciais desse processo de TV digital com o domínio tecnológico e cientifico brasileiro. Isso poderia criar as bases virtuosas de uma indústria de base tecnológica, geradora de emprego e que nos propiciasse o domínio de algum setor de atividade econômica.
\end{abstract}

O representante da Telecom manteve um discurso voltado para o consumidor e a possibilidade de termos escalabilidade de produção no set top Box (caixa conversora), fazendo com que os custos da TV digital no Brasil fossem confluentes com o padrão social do nosso país:

Devemos centrar qualquer tipo de discussão no consumidor, se você deixar cada ator vai puxar a sardinha para a sua brasa, então é função do órgão regulador do governo ou quem quer que esteja discutindo esse assunto de por o foco no consumidor e deixar os atores debaterem, porque cada um deles tem o seu interesse, e todos os interesses são lícitos. Mas você tem que fazer aquilo convergir em torno do consumidor, se você não fizer isso, você está indo, possivelmente, pelo caminho errado

O vocabulário exposto pela Indústria de Eletro-eletrônico e do Coletivo Intervozes nessa fase tiveram papel de pequena relevância conforme Diogo Moysés / Conselho diretor do Intervozes relata:

...se formou um Fórum da TV digital, composto só por empresários e uma pontinha da academia, cujo objetivo era propor as especificações técnicas para a TV digital que seriam aprovados pelo comitê de desenvolvimento, só que para compor esse comitê, além de você ter que ser uma empresa você teria que pagar alguns milhares de reais, então toda a sociedade civil ficou sem acesso ao que estava sendo discutido.

$\mathrm{O}$ mesmo ocorreu em relação à indústria de eletro-eletrônicos conforme oVice Presidente da Gradiente Eletrônica S.A., Morris Arditti:

Antes do decreto, nós, em termos de indústria, fomos muito pouco envolvidos. Eu até costumo dizer que nos meus 35 anos de carreira essa é a primeira vez que eu sento, porque a televisão alguém transmite e alguém recebe, e esses dois setores nunca sentaram juntos, pelo menos aqui no Brasil.

O texto acima mostra o pioneirismo nas discussões que posteriormente se seguiriam. Foi proposto pelos radiodifusores, sendo que, somente em 1997, o Governo, representado 
pelo COM-TV (comissão assessora de assuntos de televisão), aceita essa idéia, embora a Sociedade Civil, a Indústria de Telecom, a Indústria de Eletro-eletrônico e a Academia não compactuassem com essa urgência na implantação de um novo padrão de televisão.

\title{
$4^{\circ}$. passo - Contingências do Ato Retórico
}

Os radiodifusores, para alcançar seus interesses, deveriam omitir a relação custo/beneficio presente no empreendimento. A opção do padrão japonês se mostrava cara para a economia brasileira, visto que era uma tecnologia nova em relação aos outros dois padrões pesquisados e, por conta disso, já tinham seus custos diluídos em seus respectivos países. Roberto Franco - Presidente da SET / Diretor de Tecnologia do SBT esclarece:

\begin{abstract}
Discutiu-se muito, olha tem que discutir o modelo do negócio, tem que discutir isso e aquilo, porque o radiodifusor está induzindo, porque alguém está induzindo. A preocupação nossa e que eu acho que está a prova de quem quiser checar, o Brasil adotou a tecnologia que está mais em estado da arte e é a mais ampla (...). A plataforma é muito flexível, ela é muito robusta, ela permite, claro que não é uma coisa sem limites, claro que não é uma coisa utópica que você possa pensar, mas para o estado atual do que você tem imaginado de modelos de negócio ela suporta todos e até tem certa margem de evolução bastante grande. Eu acho um conforto muito grande um País como o nosso que está se construindo, que está se definindo, que está se rediscutindo
\end{abstract}

O Governo federal não poderia se posicionar claramente a favor das discussões, pois a influência dos radiodifusores poderia ficar bastante evidente para a população. Ara Minasian Superintendente de Comunicação de Massa da Anatel afirma:

\begin{abstract}
...o sucesso de um empreendimento ocorre quanto mais cedo a sociedade optar por aquela vertente, porque se a sociedade não optar não tem jeito você terá de buscar outra solução. Porém, nós estamos num governo que se preocupa com o lado social, e aliás todos eles deveriam se preocupar. Mas isso não quer dizer que você vai introduzir uma tecnologia excluindo uma classe, isso jamais pode estar na cabeça de alguns, ou você acha que vai introduzir uma tecnologia começando pelas classes $D$ e E; alguém tem que pagar a conta, então ou essa tecnologia começa a se tornar mais cara para as classes A e B para suportar um subsídio que existiria ou você fomenta, começa por cima e depois vai embora
\end{abstract}

Nesse momento, a academia utilizava o discurso de atacar a indústria nacional, declarando o setor como totalmente reativo a todo o processo de TV digital, contrário à altadefinição, ao padrão MPEG-4, a toda e qualquer proposta de inovação tecnológica, como relata Marcelo Zuffo, professor livre-docente da USP:

É uma indústria de imagem, é uma indústria de contrabando, é uma indústria do cinza, é uma indústria que oferece ao consumidor brasileiro uma tecnologia obsoleta sob o argumento de ser obsoleta pelo baixo custo e portanto acessível à população.

O representante da indústria de Telecom, nesse momento, não poderia ressaltar que sua tecnologia estava obsoleta em comparação à tecnologia japonesa. Ela tinha o foco na multi-programação e na portabilidade, porém não no desafio da alta-definição:

No mundo não é um grande negócio ainda, mais já está acontecendo é algo que não podemos mais classificar de embrionário. Então tudo isso vai acontecer e irá gerar uma nova dimensão para a mídia. Antigamente a gente dizia que você tinha um televisor fixo e de uso coletivo e você transmitia conteúdo em Standard Definition e 
essencialmente grátis e agora as dimensões mudam aonde o televisor agora vai para o PC ou para o Lap Top e você vai para o celular também. O televisor não é mais um televisor agora mudou bastante, o fixo está indo claramente para o móvel, mídia não é mais só mídia, agora você está juntando com Telecom e T.I. que são modelos pagos, aonde agora não é só grátis (transmissão broadcasting). O Standard Definition do passado está indo em duas grandes direções, no High Definition para telas grandes e no Low Definition para celulares, seria a idéia do uso coletivo indo para o uso pessoal.

A indústria Eletro-eletrônica não podia mostrar fraqueza no momento dos testes de análise de qualidade dos três padrões em pesquisa, pois, o setor tinha uma fragilidade no quesito de concorrência do set top box e toda a linha de produtos eletrônicos para atender o segmento da TV digital. Como destaca Morris Arditti, vice-presidente da Gradiente:

\begin{abstract}
Se fosse puramente japonês, puramente europeu, ou puramente americano, tanto faria pois a indústria brasileira iria fazer os receptores, mas iria sofrer uma concorrência daquelas empresas que já atuam com produtos nesse tipo de sistema. Ao escolher um sistema brasileiro ou qualquer um dos outros três com adaptações brasileiras isso acabou tirando a vantagem que as empresas de fora tinham no processo.
\end{abstract}

É interessante ressaltar que o Coletivo Intervozes, na fase inicial do processo de testes dos padrões, ficou literalmente excluído do debate, como descreve Diogo Moysés / Conselho diretor do Intervozes:

O Intervozes começa a ter uma participação mais efetiva a partir de 2003, assim que o Miro Teixeira assumiu o MINICOM alguns meses depois da entrada do governo Lula, e no mês de novembro culminou-se o primeiro decreto o 4901, e o então responsável da casa civil nesse período era o deputado José Dirceu, eu acho que foi o primeiro grande ponto de virada...

\title{
5.2 SEGUNDA FASE: "2003 A 2006"
}

\section{$1^{\circ}$. passo - Antecedentes da Situação}

Decorrente do período anterior, no qual foram feitos testes sobre os três sistemas Japonês (ISDB), Norte-Americano (ATSC) e Europeu (DVB) —, ficaram evidenciadas algumas discussões realizadas pelos agentes envolvidos. No final desse período, em 26 de novembro de 2003, surge o decreto 4.901/03 que privilegiava o modelo europeu e direciona o foco no sentido da democratização da informação, postura que interessava ao grupo Intervozes e aos Telecoms.

\section{$2^{\circ}$. passo - o Problema Retórico}

O Governo federal, na defesa de seus interesses, voltado para integração e desenvolvimento de tecnologia nacional, durante atuação de Miro Teixeira (em parceria com o Deputado José Dirceu) como Ministro das Comunicações, privilegia os interesses da sociedade civil, representados pelo Coletivo Intervozes, em detrimento da tecnologia que os radiodifusores defendiam.

De certo modo o decreto 4901/03 prejudicava os interesses comerciais dos proprietários das mídias televisivas, fato esse que acarretou sólida divergência com os interesses que os radiodifusores tinham em manter seu modelo de negócio baseado em publicidade. $\mathrm{O}$ referido decreto privilegiava a pulverização da mídia, possibilitando, dessa maneira, a inserção de novos players. Por isso, os radiodifusores se uniram para alterar esse decreto. Argumentavam que a tecnologia do padrão europeu (MPEG-2) estava ultrapassada e, 
se o Brasil adotasse essa tecnologia, não estaria privilegiando a alta-definição, visto que ela não contemplava tal função, utilizando apenas a faixa de $6 \mathrm{MHz}$ que estava disposta no decreto.

Para a indústria Eletro-eletrônica não interessava que fosse implantado um padrão proprietário, ou seja, puramente Japonês, Europeu ou Norte-Americano. Eles ficariam dependentes dessas tecnologias e teriam um custo mais alto para produzi-la no Brasil.

Nesse cenário, os interesses da academia estavam sendo favorecidos, visto que o Governo estava fomentando a pesquisa com repasse de verbas - chegando ao montante aproximado de 60 milhões de reais. Para a academia esse foi o melhor período. Nesse momento a academia estava interessada em desenvolver uma tecnologia 100\% nacional, dessa forma poderia exportar a tecnologia para toda América Latina. Estávamos diante de um impasse, ou, na linguagem de Burke, "diante de uma situação retórica abrangente". Tanto que a academia discordava radicalmente da Indústria de Telecom em implantar o padrão europeu, pois, propunha tecnologia nacional como gestão do conhecimento o que, certamente, conduziria ao desenvolvimento de algum setor da economia do país.

\section{$3^{\circ}$. passo- Anatomia da Mensagem}

Tanto o Governo quanto o grupo Intervozes e Telecom estavam direcionados para a possibilidade da democratização da informação, com o foco no consumidor. As palavraschave que predominaram no discurso desse período foram: democratização, integração, desenvolvimento, inclusão digital e cidadania. A "Academia" utilizava no seu discurso o desenvolvimento de uma tecnologia totalmente nacional, fomento a pesquisas e acalentando possibilidades de uso na educação à distância, caminhos para a interatividade plena. $\mathrm{O}$ discurso ressaltava, basicamente, o nacionalismo.

Nesse momento, o radiodifusor colocava a questão da alta-definição e da robustez do sinal em primeira instância de todos os debates. Contrariamente à posição do Governo Federal, Telecom e Intervozes, predominantemente voltavam-se para a tecnologia de ponta, indicavam o absurdo de se implantar um padrão superado, da qualidade em detrimento da abrangência.

A indústria de Eletro-eletrônica posicionava-se ao lado do radiodifusor, argüindo a possibilidade de uma tecnologia híbrida.

\section{$4^{0}$. passo - Contingências}

Em nenhum momento desse período o Governo aponta para questão tecnológica como determinante. Insiste sempre no aspecto social. O grupo Intervozes evita, também, qualquer referência à tecnologia. Os Telecoms insistiam no barateamento da tecnologia e escondiam o fato do sistema DVB obrigar que a veiculação do sinal de TV para celulares passe por uma operadora de telefonia. Gerando um custo adicional para o consumidor que desejasse adquirir esse serviço.

A indústria de Eletro-eletrônicos evitava fazer referência a falta de tecnologia de ponta, pois isso comprometeria seus interesses. E a academia evitava abordar a tecnologia, uma vez que o padrão europeu era inferior ao japonês. Por isso, insistiam nos aspectos sociais, como a geração de empregos. Por sua vez, os radiodifusores, em nenhum momento desse período, destacam a possibilidade da multi-programação como um diferencial dentro do sistema de TV digital, pois, essa possibilidade contrariava seus interesses.

\subsection{TERCEIRA FASE: “2006 a 2007"}

\section{$1^{0}$. passo - Antecedentes da Situação}


Essa fase inaugura um novo cenário: com a queda do Chefe da Casa Civil (o Deputado José Dirceu) e a entrada do Ministro Hélio Costa, o direcionamento toma novos rumos. É elaborado o Decreto 5820/06 (em substituição ao decreto 4901/03), estabelecendo o funcionamento da TV digital brasileira, sendo o sistema japonês escolhido para ser o padrão definitivo da TV digital no Brasil.

\section{$2^{\circ}$. passo - O problema Retórico}

O problema retórico do Governo Federal, com a mudança no Ministério e as novas alianças, agora, era outro. Era preciso enfatizar os aspectos tecnológicos em detrimento dos aspectos sociais presentes no decreto anterior (4901/03) que privilegiava, pela pressão dos Telecoms, o padrão europeu.

Os radiodifusores, de certa maneira, com seus interesses atendidos, defendendo a monoprogramação (HDTV), queriam manter o seu padrão de negócios para não pulverizar a publicidade. Deixaram de lado as críticas ao Governo e passaram, então, a criticar aqueles que não entendiam a necessidade de se adotar tecnologia de ponta, justamente aquela do padrão japonês.

O grupo Intervozes, tendo o seu foco sempre voltado para a democratização da informação, sofreu uma grande derrota em relação aos seus interesses, limitando-se à intensificar suas críticas ao padrão japonês. Enfatiza, também, que não havia necessidade de tamanha urgência nessa implantação.

Os Telecoms, por sua vez, não tinham mais como impor a sua tecnologia. Restando ao grupo, apenas, defender a existência do canal de retorno, indispensável para possibilitar a interatividade plena.

Os interesses da indústria de Eletro-eletrônicos, com o padrão híbrido definido pelo decreto, acabaram não sendo afetados. Por isso, mantiveram-se, a partir de então, indiferentes. A Academia com seu foco dúbio, também primou por certa neutralidade. Se, por um lado, foi prejudicada ao cessar o investimento em pesquisa, por outro, foi favorecida, ao se possibilitar que uma parte da tecnologia pesquisada por ela fosse contemplada dentro do sistema TV digital brasileira através do middleware Ginga.

\section{$3^{\circ}$. passo - Anatomia da Mensagem}

O Governo primou pela valorização do desenvolvimento tecnológico. O que interessava como discurso, nesse momento, era a qualidade do som e da imagem e a robustez da TV móvel (portabilidade e mobilidade). A não democratização da informação passa a ser justificada em seus discursos. Os radifodifusores enfatizaram a questão tecnológica, com termos voltados para um novo tempo: desenvolvimento, tecnologia de ponta, qualidade da programação. Os Telecoms insistiam no barateamento da tecnologia e evitavam abordar os aspectos relacionados à tecnologia de alta-definição, pois o seu sistema não comportava tal qualidade em $6 \mathrm{MHz}$.

Contrariamente a esses, o Grupo Intervozes denunciava, como anti-democrática e elitista, a posição do Governo e dos radiodifusores. Ressaltava a valorização da tecnologia em detrimento do consumidor, usando vocabulário que inseria termos como: denúncia, fraude, favorecimento, etc.

\section{$4^{\circ}$. passo - Contingências}

As omissões passaram a ser constantes; tanto o Governo Federal quanto os radiodifusores evitavam abordar a questão social, insistindo nos aspectos meramente tecnológicos. O Grupo Intervozes descaracterizava a importância da tecnologia, pretendendo valorizar os aspectos da questão social. Os Telecoms omitiam a questão da tecnologia que dispunham (que não era de alta-definição), por isso insistiam, apenas, no barateamento do sistema, justificando que o foco deveria ter sido sempre o consumidor, e nunca a indústria. A Academia omitia sua dependência do Governo, buscando passar uma imagem de 
independência. A indústria de Eletro-eletrônico escondia o alto custo dos set top Box, e pressionava o Governo para baratear os impostos dos componentes importados.

Inicialmente, os radiodifusores impulsionaram os debates sobre a implantação da TV digital no Brasil. Com a promulgação do decreto 4901/03, que indicava o padrão europeu, acirraram-se as discussões. A atuação dos radiodifusores e a sua influência sobre o Governo, mais acentuadamente, após mudança do Ministro, permitiu a promulgação do Decreto 5820/06, que conduziu a adoção do padrão japonês como definitivo.

Desse modo, dependendo da mudança do contexto, o problema retórico, a anatomia da mensagem, as contingências também se modificaram.

Até aqui, com base nos quatro passos iniciais da Análise Retórica e seu método histórico-crítico, pode-se perceber, em função das mudanças no contexto, a mudança de discurso de cada um dos agentes. Os dois passos restantes: Interpretação do Ato Retórico e Julgamento acentuarão os aspectos filosóficos dos debates.

\section{$5^{\circ}$. e $6^{0}$. passos - Interpretação e Julgamento do Discurso}

Para interpretar os diferentes discursos representativos dos interesses dos agentes envolvidos, optou-se por destacar dois posicionamentos teóricos diametralmente propostos representados pelos pensadores humanistas de um lado e, pelos pragmáticos, de outro.

Bolaño e Brittos (2005) podem ser classificados como humanistas e, Griffin (1996), defensor de uma postura mais pragmática em relação aos grupos de poder.

Assim, para Bolaño e Brittos (2005), o Grupo Intervozes, na defesa da democratização da informação, embora excluídos do Fórum de TV digital, tiveram importante papel ao denunciar os estratagemas utilizados pelos radiodifusores no sentido de cooptar o Governo Federal para atender seus interesses, em detrimento dos interesses da sociedade brasileira. Bolanõ e Brittos . (2007, p.35) afirma:

Essa baixa participação da sociedade brasileira na sua pluralidade, nas dinâmicas de regulamentação, tem-se repetido no âmbito da definição da digitalização das transmissões televisivas. Mesmo no período mais recente da história do país, fazendo-se um corte a partir do desencadeamento do processo de sua modernização com a Revolução de 30, não houve uma mudança do sentido de incorporação regular dos trabalhadores e sua visão de mundo na esfera decisória

Para Gerald Griffin, os estratagemas fazem parte integrante do mundo dos negócios, no qual a astúcia representa importante papel. Nessa perspectiva, os radiodifusores souberam manipular, habilmente, a situação que se apresentava para alcançar seus objetivos. Griffin (2007, p.35) afirma:

As lutas e as guerras de vida e morte que ocorriam nos campos de batalha agora são travados nas salas de reunião da diretoria. Os capitães de cavalaria foram substituídos por capitães de indústrias. As decisões dos generais não são a respeito de tomar colinas e vales, mas sobre a conquista de novos mercados; não são decisões sobre o tratamento a ser dispensado aos prisioneiros de guerra, mas sobre como tratar as pessoas afetadas pela compra de sua empresa.

Desse modo, dependendo da ótica com a qual se analisa a implantação da TV digital no Brasil, pode-se tanto conceber que diante das circunstâncias e da correlação de forças estabelecidas os radiodifusores foram eficientes e éticos ou mesmo eficientes e não-éticos. Em relação ao grupo Intervozes, pode-se também afirmar que, embora não contemplados em suas idéias, estiveram determinados a lutar pelos interesses democráticos da sociedade. Nesse sentido, podem ser considerados como não-eficientes, mas, profundamente éticos. 
Quanto a Indústria de Telecom, cujo interesse estava na adoção do padrão europeu pode-se considerar que não foram eficientes uma vez que seus objetivos não foram alcançados. Em relação ao aspecto ético, podem ser classificados como não-éticos, uma vez que lançaram mão de subterfúgios na mídia impressa.

Em relação aos interesses da Indústria de Eletro-eletrônicos, a escolha do modelo japonês foi indiferente. Portanto não é possível analisar o grau de eficiência alcançada. Quanto ao aspecto ético, nenhum fato de cunho moral teve relevância.

A Academia, em razão de sua subserviência às verbas governamentais, manteve uma posição dúbia: "inicialmente em oposição aos radiodifusores e, posteriormente, em favor dos mesmos". Esse procedimento pode ser classificado, na perspectiva de Bolaño, como não-ético e oportunista. Já na visão de Griffin, ele seria como natural, uma vez que, ao defender o repasse de verbas, está defendendo os interesses da instituição que representa.

Assim, de modo geral, aquele que não teve seus interesses atendidos (Grupo Intervozes, Telecom), em seu discurso, tende a valorizar os aspectos sombrios que se pode vincular ao poder - pela exploração daquilo que é negativo. Por outro lado, aqueles que impuseram seus interesses (radiodifusores, Governo Federal), fazem emergir o uso "nobre" do poder, ressaltando a legitimidade de sua atuação.

Os beneficiados, mesmo não fazendo parte do grupo de poder, tendem a permanecer neutros (Indústria de Eletro-eletrônicos). O poder é, por sua natureza, ambíguo, uma vez que não pode ser distribuído eqüitativamente. É preciso, pois, ao pesquisador, verificar a posição ocupada no contexto por aquele que assume tal ou qual postura. Deve-se verificar se está entre os que o possuem ou entre os excluídos do poder, esses últimos em clara condição de subordinação.

\section{CONSIDERAÇÕES FINAIS}

A estratégia, a retórica e a Análise Retórica constituem três marcos teóricos complementares para o estudo das negociações nos quais os executivos atuam como retores na defesa dos interesses das organizações que representam.

O termo estratégia, origina-se da palavra stratego que se refere a arte do general que deve saber quando atacar, quando recuar, quando simular. A retórica definida como a capacidade do emissor influenciar astutamente o receptor para aquilo que aquilo que interesse a ele (emissor) sem que o receptor tenha clara consciência disso (Aristóteles, 1956). A estratégia acrescida da retórica formam os estratagemas, isto é, os ardis e armadilhas empregados para se levar vantagem em determinada situação (Zaccarelli, 2000) .

O conceito de estratégia decidida continuamente, por sua característica de poder monitorar a ação dos concorrentes e oferecer a possibilidade de ser alterada continuamente propicia a busca de adesão do negociador à causa em questão por intermédio de estratagemas habilmente criados, vai além da mera persuasão proposta pela retórica antiga.

No presente trabalho esses estratagemas, na perspectiva dos teóricos da negociação da Universidade de Harvard (Bazerman 1994); (Ury,1993); (Fisher; Ury; Patton, 1991) na Nova Retórica (Perelman, 1996); metodologia proposta pela Análise Retórica (Burke, 1966); Halliday (1987) e nos princípios da Estratégia Decidida Continuamente (Martinelli e Almeida 1998); (Couglan, 1991); (Hogarth-Scott, 1999) e Zaccarelli (2000) pode-se conceber que as discussões ocorridas nas três fases do processo estiveram relacionadas às disputas de posicionamento, alicerçadas em estratégias decididas continuamente, voltadas para duas concepções distintas dos agentes fomentadores: interesses comerciais versus democratização da informação. 
Na perspectiva de Stone, Patton e Heen (1999) a maioria das negociações possui elementos comuns e dentre os quais se destaca a "negociação sobre o que aconteceu", visto que o que deveria ter acontecido no curso das interações entre os participantes conduz à necessidade de reparação do ocorrido. O Decreto 5820/06 foi determinante para a escolha do padrão japonês que atendeu, acentuadamente, os interesses comerciais dos radiodifusores que souberam manipular habilmente as situações e alcançar a adesão do Governo Federal para alcançar seus objetivos, acentuadamente, pela indicação do ex-jornalista da Rede Globo de Televisão, Hélio Costa, para ocupar o cargo de ministro das comunicações em substituição ao deputado Miro Teixeira.

De modo geral, por intermédio da análise pós-factum em consonância com os relacionados ao cenário da disputa, pode-se fazer duas afirmações pontuais:

1) O comunicador empresarial é um retor. Aquele que usa palavras e outros símbolos para argumentar em favor da organização. O conceito de argumentação é o cerne da ação retórica. Argumentos não são apenas assertivas para persuadir, mas conjuntos de razões apresentadas, nunca apenas com palavras, sempre buscando todos os recursos e comportamentos que validem as palavras.

2) O comunicador empresarial é um negociador de significados. O conceito de retórica ultrapassou a noção histórica — de arte de utilizar os meios disponíveis de persuasão — para uma definição mais abrangente e moderna: retórica é a arte de negociar significados, definindo a realidade de certo ponto de vista para exercer influência sobre situações. Dessa perspectiva, o discurso empresarial é composto por todos os aspectos da vida da organização - os comportamentos de seus membros, as decisões implementadas, os rituais e as mensagens stritu sensu - , em texto ou fala.

Para exercer influências sobre situações, o emprego do conceito de Estratégia Decidida Continuamente pode ser considerada consistente em relação às ações e, desse modo, os objetivos podem acabar por ser o resultado, e não a causa, de tal consistência. Sendo assim, é crível que a estratégia decidida continuamente se constitua por novos objetivos, como uma resultante do processo.

Portanto, as negociações no sentido decisório devem estar baseadas em uma constante adaptação por parte dos negociadores, não sendo, portanto, uma ciência abrangente, sistemática, lógica e bem programada. O sentido e a compreensão das ações só acontecem depois que elas terminam, ou seja, através de um processo retrospectivo.

As estratégias de posicionamento vencedoras foram empregadas pelo Grupo de Radiodifusores e Indústria de Eletro-eletrônicos ao cooptar o Governo Federal para seus interesses pela hábil manipulação empregada na reversão de uma situação desfavorável aos seus interesses como aquela que se apresentara por ocasião da possibilidade crescente uso do padrão europeu que remeteria à multi-programação e, consequentemente, a pulverização da publicidade, fato esse, em franca oposição aos seus interesses. A indicação de Helio Costa (ex-jornalista da Rede Globo de Televisão) para ocupar a pasta de ministro das comunicações representou a inclusão de um retor na defesa dos interesses dos radiodifusores no âmbito do governo federal. Os Telecoms, embora não tenham alcançado totalmente seus objetivos, souberam adaptar-se ao padrão escolhido.

Se, por um lado, o grupo dos radiodifusores foram os grandes vencedores no emprego das estratégias de posicionamento, por outro, os agentes fomentadores derrotados nessa disputa foram a Academia e, acentuadamente, o Grupo Intervozes, representante da sociedade civil.

O Grupo Intervozes somente solucionaria seu problema retórico pela mobilização da sociedade civil em defesa da multi-programação e, consequentemente, na defesa da democratização da informação, o que, efetivamente, apesar de todo empenho, não foi 
alcançado.

Em relação aos argumentos dominantes empregados pelos retores na defesa de seus respectivos interesses temos: o Governo Federal, ao ressaltar a integração e o desenvolvimento, justificou sua postura inovadora e moderna. O Grupo Intervozes, (um dos representantes da sociedade civil), criticou fortemente o Decreto 5820/06 pelas seguintes razões: limitado efeito democrático, a não adequação da convergência das mídias e denúncia da não- efetividade da multi-programação. Os Radiodifusores, na pretensão de manter seus privilégios, enfatizaram a necessidade da continuidade do mesmo modelo de negócio, ou seja, a troca de audiência por publicidade. As indústrias de Eletro-eletrônicos acentuaram a necessidade da interatividade, embora para esses, tanto a multi-programação, bem como a mono-programação, são aceitáveis uma vez que não provocam interferências no seu modelo de negócio. Por isso, o discurso dessa Indústria primou por um posicionamento efetivo em relação à adoção de uma tecnológica nativa que, mesmo não sendo inteiramente viável, fosse constituída com componentes nacionais. As indústrias de Telecoms posicionaram-se pela adoção do padrão Europeu de TV digital (DVB), uma vez que esse padrão, implantado em mais de cinqüenta países no mundo, casava-se melhor com seus interesses comerciais. A academia, que defendia o padrão brasileiro, buscou identificar-se com a posição do Governo Federal, visto que são dependentes das verbas de pesquisa.

É possível afirmar, portanto, que a negociação dos respectivos interesses e a solução do problema retórico de cada agente fomentador pode ser explicada a partir dos argumentos que buscaram definir a realidade de certo ponto de vista para exercer influência sobre o contexto apresentado e que podem ser assim sintetizados:

1. Tanto os representantes dos grupos que defendiam a imediata implantação do modelo japonês (Governo Federal e Radiodifusores) quanto os representantes do grupos que defendiam o adiamento e a adoção do modelo Europeu (Sociedade Civil e Telecoms), até aqueles que conservaram uma posição neutra em decorrência de seus interesses (Indústria de Eletro-eletrônica), tiveram como objetivo central a busca de seus interesses por meio da persuasão caracterizado em alguns momentos pela disposição de negociar, em outros pela declaração de franca oposição ao modelo adotado, como foi o caso do grupo Coletivo Intervozes. Faz-se necessário ressaltar que, as posições assumidas inicialmente, foram se transformando ao longo do processo. O Grupo Intervozes, por exemplo, na primeira fase dos debates (1994-2003) era favorável ao ponto de vista da academia que defendia o desenvolvimento de tecnologia cem por cento nacional. Todavia, na segunda fase (20032006) ao perceber que o padrão nacional não seria adotado, assumiu a posição de apoio ao sistema Europeu, sistema esse, que propiciava a multi-programação (democratização), em consonância com os interesses da Indústria de Telecoms, em detrimento da alta-definição presente nos modelos tanto japonês quanto norte-americano.

2. Embora os discursos apresentados pelos diferentes agentes possuam conotações retóricas diferentes o embate estratégico ocorreu em perfeita consonância com os interesses em jogo: o grupo representado pelos Radiodifusores, defensor da adoção do modelo japonês, caracterizado pela presença e unicidade do significado da mensagem transposto para um nível apologético da tecnologia no qual não há lugar para dúvidas e questionamentos acentuado pelo próprio caráter das expressões enunciadas: integração; desenvolvimento; novo tempo, qualidade e os defensores do modelo Europeu representado pela indústria de Telecoms, denunciando a falta de diálogo nas discussões e o caráter autoritário do Decreto 5820/06.

3. As mensagens alicerçadas no verossímil, no plausível, no provável acompanhadas de fortes componentes afetivos e emocionais, buscavam, concomitantemente, denunciar os procedimentos utilizados pelos grupos concorrentes ao mesmo tempo em que preservavam seus interesses. O Decreto 4901/03 que fazia menção à adoção do modelo Europeu (do qual a 
multi-programação era parte significativa) foi criticado violentamente pelos radiodifusores. $\mathrm{O}$ mesmo se deu em relação ao Decreto 5820/06 que adotou o modelo japonês (que privilegia a alta-definição e ao mesmo tempo, a mono-programação) foi criticado radicalmente pelo Grupo Intervozes e a indústria de Telecoms.

Enfim, o emprego de estratagemas retóricos pelos agentes fomentadores evidencia uma das características determinantes que possibilita a integração entre os referenciais teóricos empregados na pesquisa, isto é, as teorias da negociação, a Estratégia Decidida Continuamente, a Nova Retórica e a Metodologia da Análise Retórica nos estudos críticos da comunicação, cuja flexibilidade de respostas se torna possível pela adoção do pragmatismo radical, postura essa, que permite responder imediatamente à ação dos concorrentes por meio de uma nova estratégia de posicionamento.

Evidentemente, a técnica de respostas livres propostas por Krüger (1995) possui limitações em termos de objetividade, visto que permite inúmeros recortes por parte do pesquisador, entretanto, torna-se bastante recomendável na utilização de pesquisas relacionadas à análise pós-factum. Como sugestão para futuras pesquisas pode-se recomendar análises sobre o estado da arte no período compreendido entre dezembro de 2007 até a presente data.

\section{REFERÊNCIAS}

ANTONOFF, M. Digital TV at last? Scientific American. American Edition 296, n2, 2007, p. 70-75.

ARISTÓTELES. Arte Retórica e Arte Poética. São Paulo, Difusão Européia do Livro, 1956.

BARDIN, Laurence. Análise de Conteúdo. Lisboa, Edições 70, 1977.

BAZANINI, Roberto. Globo e Universal: Tudo a Ver. A Disputa Mercadológica pelo Imaginário Popular. Ofensiva e Contra-ofensiva Retórica. Tese de Doutorado, São Paulo, PUC/SP, 1998.

Visão Filosófica das Estratégias em Administração: Há Controvérsias e Conveniências. São Paulo, COPEC/Plêiade, 2007.

BAZERMAN, Max H.; NEALE, Margaret A. Negotiating Rationally. New York: Free Press, 1994.

BOLAÑO, César Ricardo Siqueira; BRITTOS, Valério Cruz. A Economia Política Do Mercado Brasileiro de Televisão. In: BARBOSA FILHO, André; Cosette; TOME, Takashi (orgs.) Mídias digitais: convergência tecnológica e inclusão social. São Paulo: Paulinas, 2005.

. A Televisão Brasileira na Era Digital: Exclusão, Esfera Pública e Movimentos Estruturantes. São Paulo: Paulus, 2007.

BURKE, Kenneth. A Rhetoric of Motives. Berkeley, University California Press, 1966.

CAMPBELL, Karlyn Khors. The Rhetorical Act. Belmont, California, Wadswhort, 1982. 
POSICIONAMENTO ESTRATÉGICO DOS AGENTES FOMENTADORES NA IMPLANTAÇÃO DA TV DIGITAL NO BRASIL: DISPUTAS, NEGOCIAÇÕES E ESTRATAGEMAS RETÓRICOS

COUGHAN, Anne T, ANDERSON, Erin, STERN, Louis W. Marketing Channels. 6th ed. Upper Saddle River: Prentice Hall, 2001

CROCOMO, Fernando Antonio. TV Digital Produção Interativa: A Comunidade Recebe e Manda Notícias. Tese de Doutorado. Universidade Federal de Santa Catarina, 2004.

CRUZ, Renato. Fora da Caixa: O Processo de Decisão sobre o Sistema de TV Digital no Brasil. Tese de doutorado. São Paulo, USP, 2006.

O Que as Empresas podem Fazer pela Inclusão Digital. São Paulo: Ethos, 2004.

FISHER, Roger e URY, William. Como chegar ao Sim: A Negociação de Acordos e Concessões. 3 ed. Rio de Janeiro, Imago, 1985.

FISHER, Roger, URY, William; PATTON, Bruce. Como Chegar ao SIM. Rio de Janeiro, Imago, 1991.

GALPERINI, Herman. New Television, Olds Politics: The Transition to Digital TV in United States e Britain. New York, Cambridge, Uk, 2004.

GODOY PICCOLO, Lara Schibelsky. Interação Na TV Digital : Estudo E Proposta De Aplicação Em Governo Eletrônico. Dissertação de Mestrado. São Paulo, Unicamp, 2008.

GRACIÁN, Baltasar. Agudeza y Arte de Ingenio. Madrid, Clásicos Castalia, Edición de Evaristo C. Calderon, 1987.

GRIFFIN, Gerald R. Maquiavel na Administração: Como Jogar e Ganhar o Jogo do Poder na Empresa. São Paulo, Atlas, 1996.

HALLIDAY, Tereza. Atos Retóricos. São Paulo, Summus,1986. A Retórica das Multinacionais. São Paulo, Summus, 1987.

HART, Jeffrey, A. Television, Technology, and Competition HDTV and Digital TV in The United States, Western Europe, and Japan. New York, Cambridge University Press, 2004.

HOGARTH-SCOTT. Retailer-Supplier Partnerships: Hostages To Fortune Or The Way Forward For The Millennium?. British Food Journal, 101: 9, 1999.

KRÜGER, Helmuth. Introdução à Psicologia Social. São Paulo, EPU, 1986.

MARCUSCHI, L. A. Análise da Conversação. São Paulo, Ática, 1986.

MARTINELli, Dante. ALMEIDA, Ana P. Negociação e Solução de Conflitos. São Paulo, Atlas, 1998.

MONTEZ, Carlos; BECKER, Valdecir. TV Digital Interativa: Conceitos, Desafios e Perspectivas para o Brasil. Florionapólis, UFSC, 2005.

PERELMAN, Chaim. The Realm of Rhetoric. Notre Dame, University of Notre Dame Press, 1982. 

1996.

OLBRECHTS-TYTECA, L. Tratado da Argumentação. São Paulo, Martins Fontes,

RIES, Al.; TROUTH, Jack. Posicionamento: a Batalha pela sua Mente. São Paulo: Pioneira, 1994.

STONE, Douglas .; PATTON, Bruce et HEEN, Sheila. Conversas Dificeis. Rio de Janeiro: Campus, 1999.

TORRES, Rodrigo Murtinho de Martinez. O Mercado De TV Por Assinatura No Brasil Crise E Reestruturação Diante Da Convergência Tecnológica. Dissertação de Mestrado, Rio de Janeiro, Universidade Federal Fluminense, 2005.

ZACARELLI, Sérgio Batista. Estratégia e Sucesso nas Empresas. São Paulo, Saraiva, 2000. 